\title{
Sporadic, Trauma-Induced Pancreatic Desmoid Tumor: Case Report of a Rare Disease and Literature Review
}

zhongfei zhu

Shanghai Changhai Hospital https://orcid.org/0000-0003-3312-1784

Bin Song

Second Military Medical University First Hospital: Changhai Hospital

Gang Jin ( $\sim$ jingang0201@sina.com )

Changhai Hospital

Case report

Keywords: desmoid tumor, pancreatic tumor, pancreaticoduodenectomy

Posted Date: February 17th, 2021

DOI: https://doi.org/10.21203/rs.3.rs-214030/v1

License: () (1) This work is licensed under a Creative Commons Attribution 4.0 International License. Read Full License 


\section{Abstract}

\section{Background:}

Desmoid tumor (DT) is a rare neoplasm. It is a benign tumor, but it has the potential to become invasive. The number of reported intraabdominal DT cases does not exceed 100 . The etiology is usually associated with a surgery, with the tumor occurring especially at the surgical margins. Cases induced by trauma have not been reported before.

\section{Case presentation:}

Here we report of a case of a 15-year-old boy who fell and was hit in his abdomen by his bicycle's handle. He was referred to our unit due to the yellowing of the skin and sclera. We assumed it to be pancreatic adenocarcinoma because he had obstructive jaundice, a high level of the carbohydrate antigen 19-9 and the diagnosis of abdominal magnetic resonance imaging scan, which demonstrated pancreatic cancer.Elective surgery was performed based on a presumptive diagnosis of pancreatic adenocarcinoma. Immunohistochemical analysis on the resected tumor concluded a diagnosis of pancreatic DT. After 48 months of follow up, the patient still shows no sign of recurrence.

\section{Conclusion:}

Based on the reviewed literature, curative resection is the recommended treatment for pancreatic DT, and the rate of recurrence for sporadic pancreatic DT is low.

\section{Background}

Desmoid tumor (DT), also known as desmoid-type fibromatosis or aggressive fibromatosis, is a rare soft tissue neoplasm that originates from the musculoaponeurotic structures throughout the body[1]. It is always considered benign due to its lack of metastatic potential, but it tends to be locally aggressive. It can be classified as extra-abdominal, abdominal, and intra-abdominal. From another perspective, it can be divided into sporadic or familial adenomatous polyposis (FAP)-associated. FAP with DT is called Gardner syndrome[2, 3].Sporadic intraabdominal desmoid might occur after localized trauma (surgical or nonsurgical)[4]. These tumors rarely occur in the pancreas, with only 15 cases recorded since the 1980s. Patient has provided informed consent for publication of the case.

\section{Case Presentation}

Herein we report on a case of a 15-year-old Han Chinese male who was misdiagnosed before the surgery. We assumed it to be pancreatic adenocarcinoma because he had obstructive jaundice and a high level of the carbohydrate antigen $19-9$ (CA19-9). The tumor was located at the pancreatic neck and presented as a solid lesion. The patient underwent a successful curative resection. The histopathological examination identified it as pancreatic DT. The patient exhibited no signs of recurrence or metastasis within the 48months of follow-up.

The patient, who is a student, presented to the pancreatic surgery department at our hospital with a complaint of yellow skin, sclera, and urine for over two weeks. About one month prior, he fell from the bicycle and was hit in his epigastric region by the bicycle's handle. He felt epigastric pain but without vomiting. Physical examination at a local hospital showed that the patient had a pressure-induced pain in the upper abdominal area. There was no pain elsewhere, no scratch, and no broken ribs. Blood tests revealed no signs of bleeding or acute pancreatitis. A computer tomographic (CT) scan of the upper abdomen showed no signs of gastrointestinal perforation or parenchymal viscera rupture. He was prescribed some medications and was discharged. He felt fine afterward, but two weeks later, his skin and sclera turned yellow, he felt skin itching, and had anorexia from then on. On a second visit to the hospital, magnetic resonance cholangiopancreatography (MRCP) indicated obstructive jaundice, and the patient was referred to our surgical unit. There was no radiating pain, nausea, or vomiting, and his past medical and surgical history was unremarkable. No family history was suggestive of any genetic disease.

On presentation, physical examination found him to be thin and small, with a body mass index (BMI) of 17.5. His entire body skin and the sclera were stained yellow. Abdominal palpation and auscultation revealed no abnormalities, and percussion was also normal. Liver function test showed increased bilirubin with the following values: total bilirubin, $384.2 \mu \mathrm{mol} / \mathrm{L}$ (reference range (RR): 2.0 to $18.0 \mu \mathrm{mol} / \mathrm{L}$ ), conjugated bilirubin $295.1 \mu \mathrm{mol} / \mathrm{L}$ (RR: 0 to $7 \mu \mathrm{mol} / \mathrm{L}$ ), and unconjugated bilirubin $89.1 \mu \mathrm{mol} / \mathrm{L}$ (RR: 1.7 to $13.7 \mu \mathrm{mol} / \mathrm{L}$ ). Levels of ALT and AST were $584 \mathrm{U} / \mathrm{L}$ and $275 \mathrm{U} / \mathrm{L}$ (RR: 0-64 U/L), respectively. The level of $\mathrm{Y}$-GTT was $800 \mathrm{U} / \mathrm{L}$ (RR: 0-47 U/L), and that of CA19-9 was $274.82 \mathrm{IU} / \mathrm{mL}$ (RR: 0 to $37 \mathrm{IU} / \mathrm{mL}$ ). Other serum tumor markers were within the normal range, including carcinoembryonic antigen, 1.94 $\mathrm{ng} / \mathrm{mL}$ (RR: 0 to $5 \mathrm{ng} / \mathrm{mL}$ ), and a-fetoprotein antigen, $1.95 \mathrm{ng} / \mathrm{mL}$ (RR: 0 to $8.78 \mathrm{ng} / \mathrm{mL}$ ). 
An abdominal magnetic resonance imaging (MRI) scan revealed an irregular patchy low signal area on the T1-weighted images. The mass was located in the pancreatic neck region, its size was $2.9 \mathrm{~cm}$ by $2.3 \mathrm{~cm}$, and it showed no sign of vascular or visceral invasion. It had a blurry boundary and insignificant enhancement. The pancreatic mass showed no evidence of local invasion or metastasis. The intrahepatic, common bile, and main pancreatic ducts were all moderately dilated. There was no retroperitoneal lymph node swelling. The diagnosis was a suspected pancreatic adenocarcinoma and cholecystitis (Fig. 1A-D).

Because the level of conjugated bilirubin was high, we performed percutaneous transhepatic cholangial drainage (PTCD) four days after the patient was hospitalized. Elective surgery was scheduled as this pancreatic tumor was symptomatic with a suspected diagnosis. During exploration, the mass appeared to be localized to the pancreatic neck, near the pancreatic head. It appeared invasive, but without lymph node involvement. We proceeded to perform pylorus-preserving pancreaticoduodenectomy (PPPD), and digestive tract reconstruction via pancreaticojejunostomy, choledochojejunostomy, and gastrojejunostomy The surgical procedure was uneventful and lasted approximately three hours. Blood loss was $200 \mathrm{~mL}$. The patient did not receive a blood transfusion. The postoperative course was uneventful. Parenteral nutrition was provided for seven days, and the patient was discharged on postoperative day 12 . The drainage tube was removed on postoperative day 21. The patient recovered well, with no complaints of discomfort, diabetes, dyspepsia, steatorrhea, refractory diarrhea, malnutrition, or bowel movement abnormalities, and continued his studies at school as before.

On gross pathology, the tumor size was $1.4 \mathrm{~cm} \star 1.0 \mathrm{~cm} \star 1.0 \mathrm{~cm}$. It appeared as a solid hard grayish-white mass with ill-defined margins. Histological sections showed a large number of collagen fibers that had developed into nodular lesions. The pancreatic tissue was infiltrated with tumor cells. There were no abnormalities in the pancreatic acinar cells or the ductal epithelium. The interior of the tumor was not necrotic, and the peripancreatic lymph nodes were unaffected (0/2). Immunohistochemical analysis revealed that the tumor cells expressed $\beta$-catenin (Fig. 2A), vimentin (Fig. 2B), smooth muscle actin (Fig. 2C), and calponin. The tumor cells were immunonegative for S100, CD34, and CD99. These pathological features were consistent with a diagnosis of intra-abdominal DT. The patient received no adjuvant therapy after surgery. Through 48 months of follow-up, clinical examinations and CT scans showed no sign of local recurrence or distant metastases.

\section{Discussion And Conclusions}

Desmoid tumor is a rare form of neoplasm. It is clonal fibroblastic proliferation that arises in the deep soft tissues and can be classified into extra-abdominal, abdominal, and intra-abdominal DT. It can also be divided into sporadic or familial adenomatous polyposis (FAP)associated DT. FAP-associated DT is called Gardner syndrome (GS). Intra-abdominal DT of the GS type is rarer, with an incidence rate of approximately one per million[4]. The sporadic intra-abdominal DT is even rarer. A review of the English-language literature found no more than 100 cases reported5. Only in 15 of these, the DT was found in pancreas (Table 1)[5-20].

The symptoms of DT are not typical. Rather, they depend on the location of the tumor. The 15 known cases of pancreatic DT presented symptoms that consisted primarily of abdominal discomfort, epigastric pain (10/15), and weight loss (4/15). One patient was asymptomatic, and one involved chest pain. None of the cases exhibited painless jaundice, the main symptom of pancreatic head cancer. It is unusual to see a patient with pancreatic head DT, as it normally does not obstruct the common bile duct. However, our patient had elevated levels of bilirubin and the serum tumor marker CA19-9. To the best of our knowledge, the case described here is the first DT with symptoms of jaundice and higher CA19-9 to be reported.

Of the previously reported cases, two went through two surgeries. The case reported by Bruce et al. developed DT following distal pancreatic resection[8]. The other case was found after resection of a neuroendocrine tumor. The first operation preserved about $6 \mathrm{~cm}$ of the pancreas while removing the pancreatic tail, and the DT was located on the remnant pancreatic body[5]. The etiology of the intraabdominal DT has not been well defined. A history of trauma or surgery at the site of the tumor might be one of the reasons, as in our case. The patient was injured four weeks earlier when falling from his bicycle and hurting the upper abdominal area. It took about a month, so, in our opinion, the injury might have been the cause. Among the reported cases, this is the first time for an injury to be described as the cause of pancreatic DT.

The diagnosis of pancreatic DT before surgery is challenging. The first tentative diagnosis was pancreatic cancer, as the patient had jaundice, elevated CA 19 - 9, and a solid tumor located in the neck of the pancreas. Pancreatic cancer, however, was incompatible with the patient's age. With a history of injury, we believed that acute pancreatitis could also explain the symptoms. However, the patient had no symptoms specific to pancreatitis, and the blood and urine amylase levels were normal. Moreover, it is histologically challenging to distinguish pancreatic DT from other uncommon pancreatic tumors such as gastrointestinal stromal tumor (GIST), neuroendocrine tumor, lipoma, and carcinoid tumor. For this reason, it is useful to perform immunohistochemical staining to confirm the diagnosis of pancreatic DT. Staining for $\beta$-catenin is especially useful, as both sporadic fibromatosis and fibromatosis associated with GS demonstrate

Page $3 / 8$ 
adenomatous polyposis coli (APC) gene mutation. This mutation leads to the accumulation of $\beta$-catenin in the cytosol and nucleus. Thus, special staining for $\beta$-catenin can exclude neural cells or GIST, which express CD117 and CD34 markers[7]. Therefore, the diagnosis of pancreatic DT can be established based on the histological and immunohistochemical findings.

Until now, the mainstay treatment of for pancreatic DT is complete resection, in part because of the tumor's ability to invade surrounding structures. In our case, surgery was the optimal strategy for the patient. We performed a PPPD because of the diagnosis of pancreatic adenocarcinoma. Sometimes, performing resection with a free margin is difficult because of the scope of invasion. So, for high surgical risk cases, chemotherapy or radiotherapy should also be considered. Wang and Wong reported a case of a 57-year-old woman, who presented with a 10-cm mass on the pancreatic head. They performed partial cystectomy, followed by treatment with celecoxib, a nonsteroidal anti-inflammatory drug (NSAID), for six months. By that time, the cyst lesion had completely disappeared[19]. Whether such an approach should be followed requires the support of a large controlled experiment. Surgical resection, if possible, is the preferable choice for these rare tumors.

In the report by Bruce and colleagues, it was noted that DT recurrence rate seems to differ greatly between sporadic and familial cases. The rate of recurrence among sporadic DT is low[8]. Within the 15 reported cases, the tumor recurred in only one case, and in that case, the tumor was associated with FAP. The prognosis of pancreatic DT is unknown. Recurrence has not been observed during the follow-up period after the curative resection in our case. Similarly, most reported cases of pancreatic DT had a favorable survival outcome. Our patient was observed for 48 months postoperatively and remained free of the disease.

In summary, sporadic pancreatic DT is a rare tissue tumor, which has the potential to be invasive. Pancreatic DT is challenging to diagnose and often tends to be misdiagnosed. In our case, we initially misdiagnosed it because of the obstructive jaundice and the high level of CA19-9. However, immunohistochemistry diagnosed it as pancreatic DT since it was possible to differentiate between it and other soft tissue tumors. Trauma may be the etiology of the DT in our case. Radical resection is recommended as the first line of treatment for DT. Based on the reported cases we have reviewed, the prognosis for pancreatic DT is good. Adjuvant therapy is not required, but treatment with NSAIDs might be effective for unresectable neoplasm.

\section{Abbreviations}

DT

Desmoid tumor

FAP

familial adenomatous polyposis FAP

CA19-9

carbohydrate antigen $19-9$

CT

computer tomography

MRCP

magnetic resonance cholangiopancreatography

$\mathrm{BMI}$

body mass index

RR

reference range

MRI

magnetic resonance imaging

PTCD

percutaneous transhepatic cholangial drainage

PPPD

pylorus-preserving pancreaticoduodenectomy

GS

Gardner syndrome

GIST

gastrointestinal stromal tumor

APC

adenomatous polyposis coli 
NSAID

non-steroidal anti-inflammatory drug

\section{Declarations}

Ethics approval and consent to participate\All date in this study had passed the review of the Shanghai Changhai Hospital Ethics Committee.

Consent for publication: The patient's mother had signed the consent form.

Availability of data and materials $\llbracket$ All data generated or analysed during this study are included in this published article.

Competing interests: The authors declare that they have no competing interests.

Funding: Not applicable.

Authors' contributions: Zhongfei Zhu drafted the work; Bin Song revised it; Gang Jin revised it and appoved the submiteed version.

Acknowledgements: The auhors wish to thank the patient and his family for the kind support of our study and permission to report on the case. We would like to express our gratitude to Fei Jiang for providing the pathological materials.

\section{References}

1. Gounder MM, Lefkowitz RA, Keohan ML, D'Adamo DR, Hameed M, Antonescu CR, et al. Activity of Sorafenib against desmoid tumor/deep fibromatosis. Clin Cancer Res. 2011;17:4082-90.

2. Nieuwenhuis MH, Casparie M, Mathus-Vliegen LM, Dekkers OM, Hogendoorn PC, Vasen HF. A nation-wide study comparing sporadic and familial adenomatous polyposis-related desmoid-type fibromatoses. Int J Cancer. 2011;129:256-61.

3. Roggli VL, Kim HS, Hawkins E. Congenital generalized fibromatosis with visceral involvement. A case report. Cancer. 1980;45:954-60.

4. Reitamo JJ, Häyry P, Nykyri E, Saxén E. The desmoid tumor. I. Incidence, sex-, age- and anatomical distribution in the Finnish population. Am J Clin Pathol. 1982;77:665-73.

5. Weiss ES, Burkart AL, Yeo CJ. Fibromatosis of the remnant pancreas after pylorus-preserving pancreaticoduodenectomy. $J$ Gastrointest Surg. 2006;10:679-88.

6. Amiot A, Dokmak S, Sauvanet A, Vilgrain V, Bringuier PP, Scoazec JY, et al. Sporadic desmoid tumor. An exceptional cause of cystic pancreatic lesion. JOP. 2008;9:339-45.

7. Bhattacharya B, Dilworth HP, lacobuzio-Donahue C, Ricci F, Weber K, Furlong MA, et al. Nuclear beta-catenin expression distinguishes deep fibromatosis from other benign and malignant fibroblastic and myofibroblastic lesions. Am J Surg Pathol. 2005;29:653-9.

8. Bruce JM, Bradley EL 3rd, Satchidanand SK. A desmoid tumor of the pancreas. Sporadic intra-abdominal desmoids revisited. Int J Pancreatol. 1996;19:197-203.

9. Gerleman R, Mortensen MB, Detlefsen S. Desmoid Tumor of the Pancreas: Case Report and Review of a Rare Entity. Int J Surg Pathol. 2015;23:579-84.

10. Jia C, Tian B, Dai C, Wang X, Bu X, Xu F. Idiopathic desmoid-type fibromatosis of the pancreatic head: case report and literature review. World J Surg Oncol. 2014;12:103.

11. Mourra N, Ghorra C, Arrive L. An Unusual Solid and Cystic Pancreatic Tumor in a 20-Year-Old Woman. Desmoid Tumor: Fibromatosis Gastroenterology. 2015;149:e5-6.

12. Pho LN, Coffin CM, Burt RW. Abdominal desmoid in familial adenomatous polyposis presenting as a pancreatic cystic lesion. Fam Cancer. 2005;4:135-8.

13. 13.

14. Rao RN, Agarwal P, Rai P, Kumar B. Isolated desmoid tumor of pancreatic tail with cyst formation diagnosed by beta-catenin immunostaining: a rare case report with review of literature. JOP. 2013;14:296-301.

15. Sedivy R, Ba-Ssalamah A, Gnant M, Hammer J, Klöppel G. Intraductal papillary-mucinous adenoma associated with unusual focal fibromatosis: a "postoperative" stromal nodule. Virchows Arch. 2002;441:308-11.

16. Słowik-Moczydłowska Ż, Rogulski R, Piotrowska A, Małdyk J, Kluge P, Kamiński A. Desmoid tumor of the pancreas: a case report. J Med Case Rep. 2015;9:104. 
17. Torres JC, Xin C. An unusual finding in a desmoid-type fibromatosis of the pancreas: a case report and review of the literature. J Med Case Rep. 2018;12:123.

18. Tsukamoto Y, Imakita M, Nishitani A, Ito T, Izukura M, Hirota S. Pancreatic desmoid-type fibromatosis with beta-catenin gene mutationReport of a case and review of the literature. Pathol Res Pract. 2016;212:484-9.

19. Wang YC, Wong JU. Complete remission of pancreatic head desmoid tumor treated by COX-2 inhibitor-a case report. World J Surg Oncol. 2016;14:190.

20. Xu B, Zhu LH, Wu JG, Wang XF, Matro E, Ni JJ. Pancreatic solid cystic desmoid tumor: case report and literature review. World J Gastroenterol. 2013;19:8793-8.

\section{Tables}


Table 1

Review of pancreatic desmoid tumor (DT)

\begin{tabular}{|c|c|c|c|c|c|c|c|c|c|}
\hline Reference & Sex & $\begin{array}{l}\text { Symptoms and } \\
\text { signs }\end{array}$ & $\begin{array}{l}\text { Trauma } \\
\text { or } \\
\text { previous } \\
\text { surgery }\end{array}$ & CA19-9 & Jaundice & $\begin{array}{l}\text { Tumor } \\
\text { location }\end{array}$ & Surgery & Recurrence & $\begin{array}{l}\text { Follow } \\
\text { up }\end{array}$ \\
\hline $\begin{array}{l}\text { Bruce et al. } \\
(1996)\end{array}$ & $\mathrm{M}$ & Abdominal pain & $\mathrm{DP}$ & NA & NA & Body & Partial resection & No & $\begin{array}{l}24 \\
\text { months }\end{array}$ \\
\hline $\begin{array}{l}\text { Sedivy et al. } \\
(2002)\end{array}$ & $\mathrm{F}$ & $\begin{array}{l}\text { Weight loss and } \\
\text { nausea }\end{array}$ & None & Normal & No & Head & $\begin{array}{l}\text { Whipple } \\
\text { resection }\end{array}$ & NA & NA \\
\hline $\begin{array}{l}\text { Pho et al. } \\
(2005)^{\star}\end{array}$ & M & $\begin{array}{l}\text { Chest pain and } \\
\text { weight loss }\end{array}$ & None & NA & NA & Tail & $\mathrm{DP}$ & Yes & $\begin{array}{l}24 \\
\text { months }\end{array}$ \\
\hline $\begin{array}{l}\text { Weiss et al. } \\
(2006)\end{array}$ & $\mathrm{M}$ & $\begin{array}{l}\text { Abdominal } \\
\text { fullness and } \\
\text { epigastric pain }\end{array}$ & PPPD & Normal & NA & $\begin{array}{l}\text { Body } \\
\text { and tail }\end{array}$ & $\mathrm{DP}$ & No & $\begin{array}{l}9 \\
\text { months }\end{array}$ \\
\hline $\begin{array}{l}\text { Amiot et al. } \\
(2008)\end{array}$ & $\mathrm{F}$ & $\begin{array}{l}\text { Epigastric pain, } \\
\text { nausea,vomiting, } \\
\text { and weight loss }\end{array}$ & None & Normal & No & Tail & $\mathrm{DP}$ & No & $\begin{array}{l}18 \\
\text { months }\end{array}$ \\
\hline $\begin{array}{l}\text { Polistina et al. } \\
(2010)\end{array}$ & $\mathrm{M}$ & Asymptomatic & None & Normal & No & Tail & $\mathrm{DP}$ & No & $\begin{array}{l}60 \\
\text { months }\end{array}$ \\
\hline $\begin{array}{l}\text { Xu et al. } \\
(2013)\end{array}$ & $\mathrm{M}$ & $\begin{array}{l}\text { Upper } \\
\text { abdominal pain, } \\
\text { nausea, and } \\
\text { vomiting }\end{array}$ & None & Normal & No & Body & $\begin{array}{l}\text { Central } \\
\text { pancreatectomy }\end{array}$ & No & $\begin{array}{l}20 \\
\text { months }\end{array}$ \\
\hline $\begin{array}{l}\text { Rao et al. } \\
(2013)\end{array}$ & $\mathrm{M}$ & $\begin{array}{l}\text { Left abdominal } \\
\text { painless lump }\end{array}$ & None & Normal & No & Tail & $\mathrm{DP}$ & No & $\begin{array}{l}10 \\
\text { months }\end{array}$ \\
\hline $\begin{array}{l}\text { Jia et al. } \\
\text { (2014) }\end{array}$ & $\mathrm{M}$ & $\begin{array}{l}\text { Epigastric pain } \\
\text { and weight loss }\end{array}$ & None & Normal & Yes & Head & No & No & $\begin{array}{l}24 \\
\text { months }\end{array}$ \\
\hline $\begin{array}{l}\text { Mourra et al. } \\
(2015)\end{array}$ & $\mathrm{F}$ & Epigastric pain & None & NA & NA & Body & $\mathrm{DP}$ & No & $\begin{array}{l}15 \\
\text { months }\end{array}$ \\
\hline $\begin{array}{l}\text { Gerleman et al. } \\
(2015)\end{array}$ & $\mathrm{F}$ & Abdominal pain & NA & NA & No & Tail & $\mathrm{DP}$ & No & $\begin{array}{l}12 \\
\text { months }\end{array}$ \\
\hline $\begin{array}{l}\text { Slowik- } \\
\text { Moczydlowska } \\
\text { et al. (2015) }\end{array}$ & M & Abdominal pain & NA & Normal & No & Tail & $\mathrm{DP}$ & No & $\begin{array}{l}19 \\
\text { months }\end{array}$ \\
\hline $\begin{array}{l}\text { Wang and } \\
\text { Wong (2016) }\end{array}$ & $\mathrm{M}$ & Abdominal pain & NA & Normal & No & Head & $\begin{array}{l}\text { Partial } \\
\text { cystectomy }\end{array}$ & No & $\begin{array}{l}18 \\
\text { months }\end{array}$ \\
\hline $\begin{array}{l}\text { Tsukamotoa et } \\
\text { al. (2016) }\end{array}$ & $\mathrm{F}$ & None & NA & NA & No & Body & $\mathrm{DP}$ & No & $\begin{array}{l}21 \\
\text { months }\end{array}$ \\
\hline $\begin{array}{l}\text { Torres and Xin } \\
(2018)\end{array}$ & $\mathrm{M}$ & $\begin{array}{l}\text { Abdominal pain, } \\
\text { nausea, } \\
\text { vomiting, and } \\
\text { low-grade fever }\end{array}$ & NA & Normal & No & $\begin{array}{l}\text { Body } \\
\text { and tail }\end{array}$ & $\mathrm{DP}$ & No & $\begin{array}{l}2 \\
\text { months }\end{array}$ \\
\hline
\end{tabular}

\section{Figures}



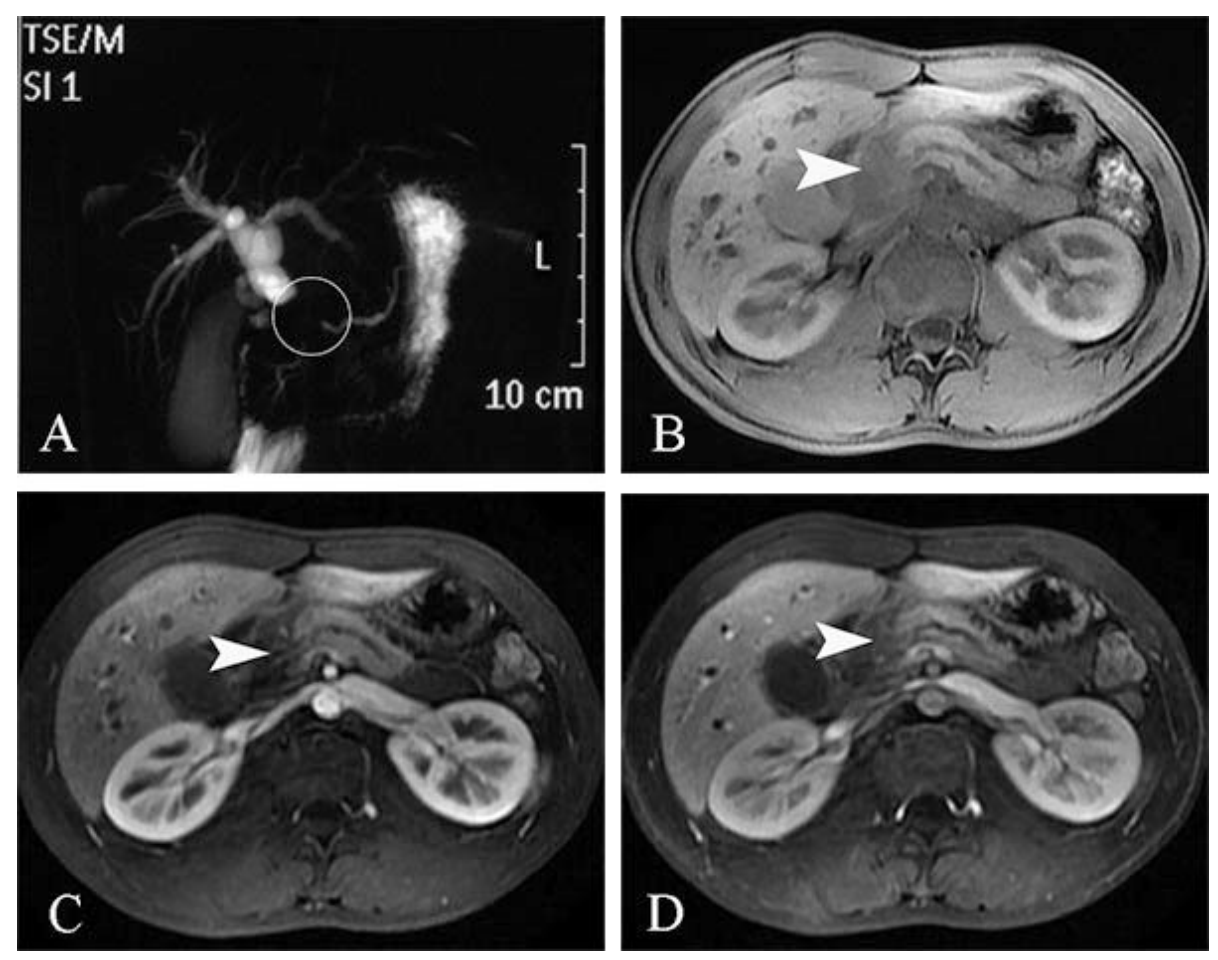

\section{Figure 1}

A-D. Enhanced pancreatic magnetic resonance images show the mass was located in the neck of the pancreas; Part A exhibits dilation of the common bile and main pancreatic ducts; Part B exhibits irregular patchy low signal on T1-weighted images, the boundary was unclear; Part $C$ and $D$ exhibit insignificant enhancement of the mass on arterial phase and portal vein phase.
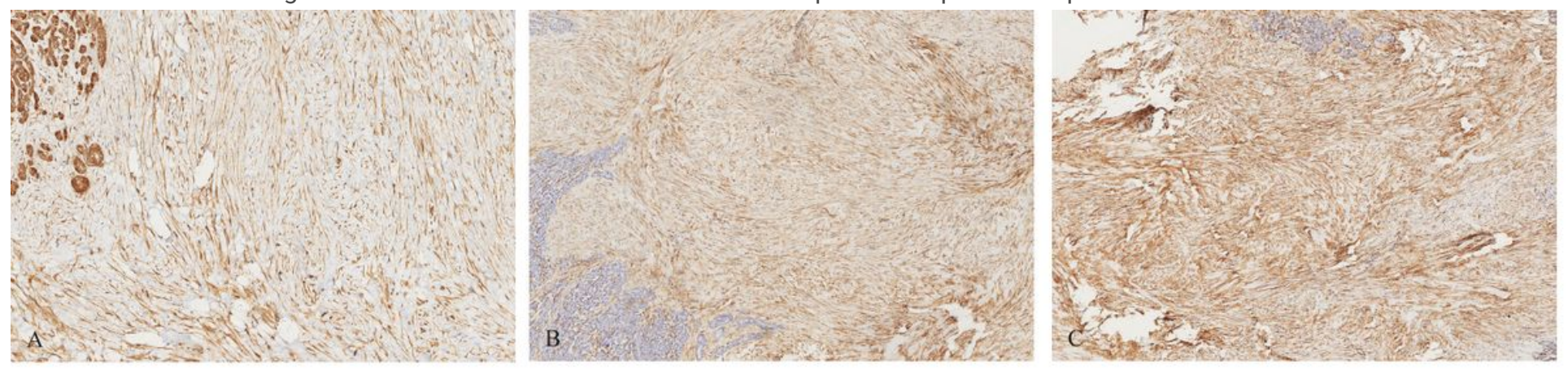

Figure 2

A. Histopathology of the pancreatic neck desmoid tumor, immunohistochemistry (200x) showing immunopositive against $\beta$-catenin. B. Histopathology of the pancreatic neck desmoid tumor, immunohistochemistry (200x) showing immunopositive against vimentin. C. Histopathology of the pancreatic neck desmoid tumor, immunohistochemistry (200x) showing immunopositive against smooth muscle actin. 